\title{
Diagnosis and treatment of cervical intraepithelial neoplasia in general practice
}

\author{
D B Johnson, C J Rowlands
}

Abstract

Objective-To audit the first five years of a colposcopy and treatment service for cervical dysplasia established within a general practice.

Design-A cervical smear register was established to determine which women were "at risk" of dysplasia. The results of colposcopy and treatment of dysplasia were analysed.

Setting-A large rural general practice with community hospital facilities in mid-Wales.

Patients -4437 Women at risk in a total practice population of 14100 .

Interventions-Colposcopy of women with dyskaryotic smear results, persistent inflammatory smear results, or vulval warts. Treatment of women with proved dysplasia by electrodiathermy of the cervix or cone biopsy.

Results-138 Women with dysplasia were diagnosed over five years: 36 mild, 97 moderate or severe, and five with microinvasion. Despite a $78 \%$ smear rate of at risk women over five years, nine invasive cancers still occurred.

Conclusions - The results of treatment are acceptable. Cervical dysplasia has become very common, the risk of a dysplasia in women aged 20-39 who had smear tests being one in 14 over five years.

\section{Introduction}

The past 10 years have seen a considerable increase in cervical intraepithelial neoplasia in the United Kingdom, ${ }^{12}$ and in particular a rising incidence of invasive cervical carcinoma in younger women. ${ }^{13}$ To combat this many more cervical smears are being performed and the workload of cytology laboratories and colposcopy clinics continues to rise. This has prompted suggestions that some of this work could be undertaken after suitable training by community physicians and general practitioners. ${ }^{4-6}$ We have developed a colposcopy service within a large rural general practice and have analysed the results of cytology, colposcopy, and treatment for a defined population over five years.

\section{Patients and methods}

Brecon is a market town in mid-Wales served by a single practice of eight partners and two trainee general practitioners. Our colposcopy service began in 1984. Patients are referred within the practice after receiving an abnormal smear result and are counselled by the gynaecological partner (DBJ) and given an explanatory sheet. Colposcopy (with a Zeiss OMPI 1FC colposcope) is performed in a standard manner with application of $5 \%$ acetic acid, and biopsy specimens are taken with punch biopsy forceps from the worst affected acetowhite areas. Patients are seen in the surgery a week later to discuss their results and the treatment proposed. Providing that the changes are preinvasive and the whole transformation zone can be seen the transformation zone is destroyed by electrodiathermy to $7 \mathrm{~mm}$ depth under general anaesthesia as a day case. If the changes go into the cervical canal and the upper extent of the transformation zone cannot be clearly seen or if features of biopsy specimens suggest microinvasion cone biopsy is performed as a 48 hour admission. This procedure is performed without sutures with Monsel's solution and a vaginal pack to achieve haemostasis. ${ }^{?}$

The total practice population is 14100 ( 7200 female, 6900 male) of which 4894 are women aged 15-69. The social class distribution is fairly typical of England and Wales as a whole but with a strong emphasis on farming and a considerable number of army families. The annual turnover of patients is low by national standards $(6 \%$ moved into and out of the practice in 1988).

A cervical smear register was compiled for the practice in late 1988 by printing out the age-sex register of women by year from the practice computer and then manually going through each patient's records (about 40 each hour) recording their smear data in year columns. We could therefore calculate for each age group abnormality rates, hysterectomy rates, and smear rates and identify patients who had never had a smear and those long overdue for a smear.

\section{Results}

Patients at risk and smear rates - Table I lists the total number of women in each age group and the number considered to be at risk of cervical neoplasia by excluding women who had had hysterectomies, nuns, and single mentally handicapped women. Within the at risk group no attempt was made to distinguish women by marital state as this is an unreliable guide to sexual activity; thus "single never sexually active" are included and the overall number of women at risk aged $15-69$ is an overestimate. The true at risk group (that is, ever sexually active) is probably $90-95 \%$ of the number given. To achieve a reduced mortality from cervical cancer as in other countries it is claimed that screening needs to reach $80 \%$ of eligible women. ${ }^{8}$ Taking the age range 20-64 our three and five year cervical smear rates were $62 \%$ and $78 \%$ of at risk women. During 1984-8, 5500 smears were performed on 3012 women in a group of 4437 at risk women aged $15-69 ; 635$ smears were follow up smears after colposcopy performed by the practice. Of the routine screening smears 3401 $(70 \%)$ were performed in the practice, $1413(29 \%)$ in family planning and well woman clinics run by community physicians, and $51(1 \%)$ by the visiting consultant gynaecologist. A total of 2684 smears were performed during 1983-5 and 3589 during 1986-8, an increase of $34 \%$.

Married, divorced, and widowed women who had never 


\begin{tabular}{|c|c|c|c|c|c|c|c|c|c|}
\hline $\begin{array}{l}\text { Age } \\
\text { (years) }\end{array}$ & No of women & $\begin{array}{l}\text { New patients' } \\
\text { records not } \\
\text { received }\end{array}$ & $\begin{array}{c}\text { No with } \\
\text { hysterectomy }\end{array}$ & No of nuns & $\begin{array}{c}\text { No of single } \\
\text { mentally } \\
\text { handicapped }\end{array}$ & $\begin{array}{c}\text { No of women } \\
\text { at risk }\end{array}$ & $\begin{array}{c}\text { No }(\%) \\
\text { smeared in } \\
\text { past three } \\
\text { years }\end{array}$ & $\begin{array}{c}\text { No }(\%) \\
\text { smeared in } \\
\text { past five years }\end{array}$ & $\begin{array}{c}\text { No }(\%) \\
\text { married, } \\
\text { divorced, } \\
\text { widowed } \\
\text { women never } \\
\text { smeared }\end{array}$ \\
\hline $15-$ & 505 & 9 & & & 4 & 492 & $76(15)$ & $79(16)$ & \\
\hline $20-$ & 397 & 7 & & 1 & 4 & 385 & $246(64)$ & $298(77)$ & \\
\hline $25-$ & 448 & 20 & & & 4 & 424 & $311(73)$ & $359(85)$ & $8 / 269(3)$ \\
\hline $30-$ & 455 & 12 & 3 & & 2 & 438 & $306(70)$ & 348 (79) & $10 / 343(3)$ \\
\hline $35-$ & 525 & 7 & 10 & & 3 & 505 & $353(70)$ & $432(86)$ & $13 / 430(3)$ \\
\hline $40-$ & 526 & 8 & 31 & 1 & 2 & 484 & $322(67)$ & $404(83)$ & $16 / 408(4)$ \\
\hline $45-$ & 421 & 5 & 48 & & 4 & 364 & $224(62)$ & $296(81)$ & 27/304 (9) \\
\hline $50-$ & 349 & & 56 & 5 & 5 & 283 & $179(63)$ & $222(78)$ & $24 / 239(10)$ \\
\hline $55-$ & 376 & 1 & 53 & & 5 & 317 & $148(47)$ & $216(68)$ & $43 / 259$ (17) \\
\hline $60-$ & 456 & 3 & 62 & 2 & 3 & 386 & $141(37)$ & $212(55)$ & $48 / 283(17)$ \\
\hline $65-69$ & 436 & 3 & 68 & 1 & 5 & 359 & $97(27)$ & $146(41)$ & $110 / 301(36)$ \\
\hline Total & 4894 & & & & & 4437 & 2403 & 3012 & 229 \\
\hline
\end{tabular}

$\star$ Excluding women for whom marital state was uncertain.

had a smear-Table I also shows the proportion of married or previously married women who had never had a smear, after excluding women who had had hysterectomies, etc. As age increased, the proportion of married or previously married women who had never had a smear increased. Overall smear rates also declined in older women. Inevitably some cases of advanced cervical cancer will occur in older women who have never had a smear or have done so only infrequently.

Smear rates and younger women-The custom of having cervical smears is well established in younger women and often follows on from attending their general practitioner for oral contraception. Table II gives the proportions of young women who were taking oral contraceptives or had been doing so in the past year (judged from the clinical notes or the form 1001) and the proportion who had had a cervical smear. At age $20,57(72 \%)$ at risk women were or had recently been taking the pill and $52(66 \%)$ had had a cervical smear.

TABLE II -Oral contraception and cervical smears by age

\begin{tabular}{cccc}
\hline Age (years) & No of women & $\begin{array}{c}\text { No (\%) taking pill currently } \\
\text { or in past year }\end{array}$ & $\begin{array}{c}\text { No }(\%) \\
\text { smeared }\end{array}$ \\
\hline 15 & 92 & $6(7)$ & $1(1)$ \\
16 & 110 & $12(11)$ & $4(4)$ \\
17 & 117 & $25(21)$ & $17(15)$ \\
18 & 99 & $34(34)$ & $25(25)$ \\
19 & 74 & $42(57)$ & $29(39)$ \\
20 & 79 & $57(72)$ & $52(66)$
\end{tabular}

Results of cervical smears-Table III shows the rates of abnormal smear results for those at risk women who had had a cervical smear in the past five years. Overall, of 3012 at risk women who were smeared, 118 had inflammatory smears (seven with koilocytosis also), 47 had mild dyskaryosis, 37 had moderate dyskaryosis, 42 had severe dyskaryosis, and 10 had malignant cells, making 89 patients (3\%) with moderate dyskaryosis or worse. Inflammatory smear results occurred in all age groups, with more in women under 45 . Mild dyskaryosis is most common in women aged 15-24 and moderate or severe dyskaryosis more common in

TABLE III - Rates of abnormal smear results for women who had had smear in past five years

\begin{tabular}{lccccccc}
\hline & & $\begin{array}{c}\text { No(\%) with } \\
\text { inflammatory } \\
\text { smear result } \\
(2 / 1)\end{array}$ & $\begin{array}{c}\text { No(\%) with } \\
\text { mild } \\
\text { dyskaryosis }\end{array}$ & $\begin{array}{c}\text { No(\%) with } \\
\text { moderate } \\
\text { dyskaryosis }\end{array}$ & $\begin{array}{c}\text { No(\%) with } \\
\text { severe } \\
\text { dyskaryosis }\end{array}$ & $\begin{array}{c}\text { No(\%) with } \\
\text { malignant } \\
\text { cells }\end{array}$ & $\begin{array}{c}\text { No (\%) with } \\
\text { moderate } \\
\text { dyskaryosis } \\
\text { or worse }\end{array}$ \\
\hline $15-$ & 377 & $15(4)$ & $20(5 \cdot 3)$ & $7(1 \cdot 9)$ & $4(1)$ & $2(0 \cdot 5)$ & $13(3 \cdot 4)$ \\
$25-$ & 707 & $39(5 \cdot 5)$ & $9(1 \cdot 3)$ & $17(2 \cdot 4)$ & $19(2 \cdot 7)$ & $4(0 \cdot 6)$ & $40(5 \cdot 7)$ \\
$35-$ & 836 & $36(4 \cdot 3)$ & $13(1 \cdot 6)$ & $9(1 \cdot 1)$ & $14(1 \cdot 7)$ & $1(0 \cdot 1)$ & $24(2 \cdot 9)$ \\
$45-$ & 518 & $12(2 \cdot 3)$ & $5(1)$ & $4(0 \cdot 8)$ & $4(0 \cdot 8)$ & $1(0 \cdot 2)$ & $9(1 \cdot 7)$ \\
$55-$ & 574 & $16(2 \cdot 8)$ & & & $1(0 \cdot 2)$ & $2(0 \cdot 3)$ & $3(0 \cdot 5)$ \\
\hline Total & 3012 & $118(3 \cdot 9)$ & $47(1 \cdot 6)$ & $37(1 \cdot 2)$ & $42(1 \cdot 4)$ & $10(0 \cdot 3)$ & $89(3)$ \\
\hline
\end{tabular}

women aged 25-34. After the age of 44 abnormal smear results become less common.

\section{COLPOSCOPY}

During 1984-8, 152 colposcopies were performed for primary investigation: 122 for dyskaryosis or worse, 19 for two successive inflammatory smear results, three with koilocytic changes, and eight with vulval warts though normal smear results. Fourteen patients with mild dyskaryosis or worse were referred elsewhere because of holidays, preference, etc. Colposcopies were performed on a further 12 patients with abnormal smear results on follow up after treatment, making 164 colposcopies in all (an average of 33 a year). In fact many more were done: colposcopy was often repeated to confirm findings immediately before treatment.

\section{TREATMENT}

We used electrodiathermy of the cervix if the whole transformation zone could be seen and invasion excluded or cone biopsy if either condition could not be fulfilled. During 1984-8 we treated 114 cases of cervical intraepithelial neoplasia and five cases of microinvasion with these methods. Table IV shows the methods used by age. Microinvasion was always treated by cone biopsy as a minimum.

TABLE IV-Methods of treatment for cervical intraepithelial neoplasia by age (119 treated)

\begin{tabular}{lccc}
\hline Age (years) & No of women & $\begin{array}{c}\text { No treated } \\
\text { with diathermy }\end{array}$ & $\begin{array}{c}\text { No given } \\
\text { cone biopsy }\end{array}$ \\
\hline $15-$ & $10^{\star}$ & 9 & \\
$20-$ & $212^{\star}$ & 21 & \\
$25-$ & 20 & 14 & 6 \\
$30-$ & 25 & 10 & 10 \\
$35-$ & 7 & 10 & 15 \\
$40-$ & 7 & 4 & 3 \\
$45-$ & 8 & 1 & 6 \\
$50-$ & 1 & 1 & 7 \\
$55-$ & 1 & & 1 \\
$60-64$ & 122 & 70 & 49 \\
\hline
\end{tabular}

^Treatment deferred in one patient because of pregnancy.

$\dagger$ Treatment declined by one patient in favour of homoeopathy.

Success rate-Treatment was followed by a three year regimen of cervical smears to check that abnormal cells were no longer being produced. Controversy exists regarding the best method of follow up: smears alone, smears and colposcopy, or smears and colposcopy and biopsy? We followed the policy of our nearest district general hospital and others in using smears alone. Early follow up smears were taken with an Aylesbury spatula but later follow up smears are now done with a two slide technique, one for the ectocervix with an Ayre's spatula and one for the 
TABLE V-Duration (years) of negative smear results on follow up (119 treated)

\begin{tabular}{ccc}
\hline $\begin{array}{c}\text { Time (years) } \\
\text { in which } \\
\text { results }\end{array}$ & Method of treatment \\
\cline { 2 - 3 } achieved \\
\cline { 3 - 3 } $\begin{array}{c}\text { negative } \\
\text { smear }\end{array}$ & Diathermy* $\begin{array}{c}\text { Cone } \\
\text { biopsyt }\end{array}$ \\
\hline$\geqslant 3$ & 10 & 10 \\
$2-<3$ & 10 & 10 \\
$1-<2$ & 19 & 15 \\
$<1$ & 21 & 10 \\
\hline & 60 & 45
\end{tabular}

^Three defaulted or moved away, seven had recurrences, therefore total $=70$

†Two defaulted or moved away,

two had recurrences therefore

total $=49$. cervical canal with a Cytobrush. If all results were negative the patient returned to two yearly smears thereafter. If recurrences occurred they were usually in the first year of follow up and often seen in the first smear result. Tables $\mathrm{V}$ and VI show the results of treatment. As most recurrences are detected in the first or second cervical smear we used a one year cure rate as a measure of success of treatment. On this basis electrodiathermy had a cure rate of $85 \%$ after one year and cone biopsy a cure rate of $95 \%$ after one year. All but one case was cured by two years.

Complications of treatment-In 70 patients treated with electrodiathermy there were two cases of primary haemorrhage from the diathermised cervix, which were treated by vaginal packing, and two cases of secondary infection, which were treated with antibiotics and bed rest. Among the 49 patients treated with cone biopsies secondary haemorrhage requiring packing and antibiotics occurred twice. Pelvic pain persisted after cone biopsy in two patients and required hysterectomy. A further patient suffered menorrhagia and persistent dysplasia within the cervical canal (case 8) and required hysterectomy.

CERVICAL DYSPLASIA AND CERVICAL MALIGNANCY BY AGE

Table VII shows the distribution of cervical abnormality by age group for the years 1984-8. For each woman the age at diagnosis was used and these figures are shown in comparison with the total number of women and also the number deemed at risk in each age group at the end of 1988. For this to be a true picture of cervical pathology in the practice population at the end of 1988 five patients who had moved away during the five years were excluded and seven new patients treated elsewhere included, as were 14 patients with dysplasia referred and treated elsewhere.

The maximum prevalence of cervical intraepithelial neoplasia grade I (mild dysplasia) was seen in women aged 15-29 and for grade II (moderate) and III (severe) was in women aged 20-39. In women aged 20-39 one in 14 women who had a smear test developed a dysplasia

TABLE VI-Treatment for nine women in whom condition recurred

\begin{tabular}{|c|c|c|c|c|c|c|}
\hline Case No & $\begin{array}{l}\text { Original CIN } \\
\text { grade }\end{array}$ & $\begin{array}{c}\text { First } \\
\text { treatment }\end{array}$ & $\begin{array}{l}\text { Time (months) } \\
\text { to recurrence }\end{array}$ & $\begin{array}{l}\text { Final CIN } \\
\text { grade }\end{array}$ & $\begin{array}{l}\text { Subsequent } \\
\text { treatment }\end{array}$ & $\begin{array}{l}\text { Time (months) } \\
\text { since last } \\
\text { positive result }\end{array}$ \\
\hline 1 & II & Diathermy & 3 & I & Diathermy & 24 \\
\hline \multirow[t]{2}{*}{2} & I & Diathermy & 3 & I & Diathermy & 16 \\
\hline & & & 3 & II & Diathermy & \\
\hline \multirow[t]{2}{*}{3} & II & Diathermy & $\left\{\begin{array}{l}3 \\
6\end{array}\right.$ & II & Cone biopsy & \\
\hline & & & 6 & I & Diathermy & $\begin{array}{r}3 \\
24\end{array}$ \\
\hline 4 & II & Diathermy & 3 & I & Diathermy & 24 \\
\hline 5 & II & Diathermy & 3 & II & Cone biopsy & 24 \\
\hline 6 & I & Diathermy & 6 & I & Cone biopsy & 9 \\
\hline 7 & III & Diathermy & 3 & I & Diathermy & 33 \\
\hline 8 & III & Cone biopsy & 3 & I & Hysterectomy & 15. \\
\hline 9 & III & Cone biopsy & 3 & III & Hysterectomy & 39 \\
\hline
\end{tabular}

$\mathrm{CIN}=$ cervical intraepithelial neoplasia.

TABLE VII -Cervical pathology during 1984-8 for practice population at end of 1988

\begin{tabular}{|c|c|c|c|c|c|c|c|c|c|}
\hline \multirow[b]{2}{*}{ Age (years) } & \multirow{2}{*}{$\begin{array}{c}\text { Total at } \\
\text { risk }\end{array}$} & \multirow{2}{*}{$\begin{array}{c}\text { Total smeared } \\
\text { in past five } \\
\text { years }\end{array}$} & \multirow{2}{*}{$\begin{array}{l}\text { No with } \\
\text { CIN }\end{array}$} & \multicolumn{3}{|c|}{ No with } & \multirow{2}{*}{$\begin{array}{c}\text { No with } \\
\text { microinvasions }\end{array}$} & \multirow{2}{*}{$\begin{array}{c}\text { No with } \\
\text { invasions }\end{array}$} & \multirow{2}{*}{$\begin{array}{l}\text { Risk of } \\
\text { CIN }^{\star}\end{array}$} \\
\hline & & & & CIN I & CIN II & CIN III & & & \\
\hline $15-$ & 492 & 79 & 11 & 7 & 3 & 1 & & & \\
\hline $20-$ & 385 & 298 & 22 & 9 & 6 & 7 & & & 1 in 14 \\
\hline $25-$ & 424 & 359 & 27 & 7 & 7 & 12 & 1 & & 1 in 13 \\
\hline $30-$ & 438 & 348 & 24 & 5 & 5 & 11 & 3 & 2 & 1 in 14 \\
\hline 35. & 505 & 432 & 29 & 2 & 7 & 20 & & 2 & 1 in 15 \\
\hline $40-$ & 484 & 404 & 8 & 3 & 1 & 4 & & & 1 in 50 \\
\hline 45- & 364 & 296 & 7 & 3 & 1 & 2 & 1 & & 1 in 42 \\
\hline $50-$ & 283 & 222 & 8 & & 2 & 6 & & 1 & 1 in 28 \\
\hline $55-$ & 317 & 216 & 1 & & & 1 & & $1 \dagger$ & 1 in 216 \\
\hline $60-$ & 386 & 212 & 1 & & & 1 & & & 1 in 212 \\
\hline \multirow[t]{2}{*}{$65-69$} & 359 & 146 & & & & & & $2(1 \dagger)$ & \\
\hline & 4437 & 3012 & 138 & 36 & 32 & 65 & 5 & $9 \ddagger$ & \\
\hline
\end{tabular}

*No with CIN out of total No of women smeared.

†Two patients with invasive carcinomas presented with bleeding.

$\ddagger$ Seven presented with abnormal smear results.

$\mathrm{CIN}=$ cervical intraepithelial neoplasia. of some severity in the five years $1984-8$ or one in 18 of all women of those ages. Because of false negative smear results and inflammatory smears and because many women have smears erratically we cannot say what proportion were new cases (incidence) in the five years under study. Over half $(73 ; 53 \%)$ of women with dysplasia had had a normal smear result in the three years (1981-3) before the study or had reached the age of sexual activity (15-19) during the study. Others had had a preexisting inflammatory smear result or dyskaryosis $(10(7 \%))$ or a negative smear result before $1981(16(12 \%))$ or no previous smear $(39(28 \%))$.

The nine cases of invasive cancer are disturbing. Four of the nine were in their 30 s and three of these had followed Department of Health guidelines and had had a previous negative smear result five years before. Of the five older women, three had not had a previous smear (two of these had presented with bleeding and one after the smear result) and two had had a smear but over 10 years before. One of the older patients presenting with vaginal bleeding had developed carcinoma of the cervical stump after a subtotal hysterectomy for fibroids 20 years before: a classic illustration - no cervical smears had been performed.

The frequency and quality of smears are obviously important. Our results show that not all women have regular smears. In addition, smears may not always be taken from the area most at risk, the squamocolumnar junction. This is reflected in the disparity of smear results and the final histological diagnosis. Of 47 women with mildly dyskaryotic smears, $19(41 \%)$ showed mild dysplasia at histological examination, 18 (39\%) showed moderate or severe dysplasia, one $(2 \%)$ showed microinvasion, and two (4\%) showed invasion (both lesions within the cervical canal). This disparity and the tendency of smears to underestimate the severity of lesions is widely recognised..$^{9-11}$ We are increasingly using Aylesbury spatulas to improve sampling. 1213

\section{Discussion}

The colposcopy and treatment service that we have established has arisen according to local need in a rural area and in a practice with a tradition of surgery. It is not necessarily applicable to other areas, though if an area has a community hospital it could well be so. Colposcopy and the treatment of dysplasia, especially by cone biopsy, require equipment, facilities, and training and this is generally more applicable in hospitals. Paradoxically much of the counselling and follow up cytology are well suited to the personalised continuing care that a general practitioner can provide. There is considerable scope for general practitioners to take part in all aspects. The creation of an excellent record system and smear register have simplified problems and ensured that defaulters are spotted. We estimate the total workload for our size of practice at $11 / 2$ hours of clinical and $1 \frac{1 / 2}{2}$ hours of clerical time a week. Our use of electrodiathermy has produced an acceptable cure rate and a low number of complications ${ }^{14}$; it is cheap and therefore readily available. The disadvantage is that general anaesthesia is required, albeit for only a few minutes. We are currently exploring loop excision diathermy as an alternative.

We have shown the considerable prevalence of cervical dysplasia in a fairly static rural population. From our figures, one in 14 women aged 20-39 having smear tests are likely to experience cervical dysplasia over a five year period. In older women the risk is lower, about one in 30-200. Cervical cytology, colposcopy, and treatment of dysplasia seem to be holding in check most but not all developing dysplasia, especially in younger women. Nevertheless, despite a five year smear rate of almost $80 \%$, nine cases of 
invasive cervical carcinoma still occurred. How can we improve?

All women at risk need good quality smears taken every three years. We need to concentrate particularly on those women under 40 who have erratic smear results. If their rate of dysplasia is the same as those who regularly have smears clearly they are at considerable risk. Our figures also show, like others, that a considerable proportion of invasive carcinomas also occur in older women, many of whom have never had a smear. ${ }^{15} 16$ Standing and Mercer have shown that a highly motivated health care team can achieve smear rates of $96 \%$ of eligible women by using nurses and doctors. ${ }^{17}$ Doctors are often pressed for time, and the use of health visitors and nurses is probably essential in achieving high smear rates such as these and in solving the problem of older women who have never had a smear.

We were surprised to discover that we were prescribing oral contraceptives (of proved efficacy and acceptability) to such a high proportion of young women. A possible association between oral contraception and cervical cancer has been reported by Beral $e t a l^{18}$ and Vessey et $a l,,^{19}$ which may be indirect. Failure to use barrier contraception at a younger age may be setting the stage for subsequent dysplasia. A change in attitudes and contraceptive usage should perhaps be considered by the patients themselves.

We thank the pathology service at Nevill Hall Hospital, Abergavenny, particularly Dr Kellet, Dr Scott, and Mrs King; Miss A Ward; Mr D G Daniel; the staff of the Powys Family Practitioner Committee; the Brecon Hospital secretarial staff and ward sisters; the Breconshire Hospitals league of friends, who provided the colposcope with which so much of this work was done; the partners and staff of our practice; and Miss Jayne Owen-Lowe for typing and retyping the manuscript.

1 Office of Population Censuses and Surveys. Cancer statistics. London: HMSO, 1986. (MB Series.)

2 Royal College of Obstetricians and Gynaecologists, Royal College of Pathologists, Royal College of General Practitioners, Faculty of Community Medicine. Report of the intercollegiate working party on cervical cytology Medicine. Report of the intercollegiate

3 Paterson MEL, Peel KR, Joslin CAF. Cervical smear histories of 500 women with invasive cervical cancer in Yorkshire. Br Med f 1984;289:896-8.

4 Chomet J. Screening for cervical cancer: a new scope for general practitioners? Results of the first year of colposcopy in general practice. $\mathrm{Br}$ Med $\mathcal{F}$ 1987;294:1326-8.

5 Walker P, Singer A. Colposcopy: who, when, where and by whom? Br f Obstet Gynaecol 1987;94:1011-2.

6 Kitchener HC, Burnett RA, Wilson ESB, Cordiner JW. Colposcopy in a family planning clinic: a future model? $\mathrm{Br} \mathrm{Med} \mathrm{F}$ 1987;294:1313-5.

7 Davis JR, Steinbronn KK, Graham AR, Dawson BV. Effects of Monsel's solution in uterine cervix. Am $\mathcal{F}$ Clin Pathol 1984;82:332-5.

8 British Medical Association. Cervical cancer and screening in Great Britain. London: BMA, 1986

9 Soutter WP, Wisdom S, Brough A, Monaghan JM. Should patients with mild atypia in a cervical smear be referred for colposcopy. Br 7 Obstet Gynaecol 1986;93:70-4.

10 Bolger BS, Lewis BV. A prospective study of colposcopy in women with mild dyskaryosis or koilocytosis. Brf Obstet Gynaecol 1988;95:1117-9.

11 Walker EM, Dodgson J, Duncan ID. Does mild atypia on a cervical smear warrant further investigation. Lancet 1986;ii:672-3.

12 Blenkinsopp WK, Jenkins JL. Cervical smears: choice of spatula is critical. Lancet 1986;ii:986.

13 Wolfendale MR, Howe-Guest R, Usherwood MM, Draper GJ. Controlled trial of a new cervical spatula. BrMed f 1987;294:33-5.

14 Giles JA, Walker PG, Chalk PAF. Treatment of cervical intra-epithelial neoplasia $(\mathrm{CIN})$ by radical electrocoagulation diathermy: 5 years' experience. Brf Obstet Gynaecol 1987;94:1089-93.

15 Ellman R, Chamberlain J. Improving the effectiveness of cervical cancer screening. I R Coll Gen Pract 1984;34:537-42.

16 Chisholm D, Haran D. Cases of invasive cervical cancer in the north west in spite of screening. British fournal of Family Planning 1984;10:3-8.

17 Standing P, Mercer S. Quinquennial cervical smears: every woman's right and every general practitioner's responsibility. Br Med f 1984;289:883-6.

18 Beral V, Hannaford P, Kay C. Oral contraceptive use and maligancies of the genital tract. Lancet 1988 ;ii: $1331-5$.

19 Vessey MP, McPherson K, Lawless M, Yeates D. Neoplasia of the cervix uteri and contraception: a possible adverse effect of the pill. Lancet 1983;ii:930-4.

(Accepted 4 September 1989)

\section{BOOKS RECEIVED}

\section{Health care issues}

Studies in Philosophy and Health Policy. "The Misfortunes of Others: End Stage Renal Disease in the United Kingdom." T Halper. (Pp xii +219 ; £25.) New York: Cambridge University Press, 1989. ISBN 0-521-35047-6.

\section{Human reproduction}

Beyond Conception: the New Politics of Reproduction. P Spallone. (Pp ix +251 £25.) London: Macmillan, 1989. ISBN 0-333-43531-1.

The Reproductive Health of Adolescents: a Strategy for Action. Joint WHO/
UNFPA/UNICEF statement. (Pp 18; UNFPA/UNICEF statement. (Pp 18; Sw frs 3 paperback.) Geneva: World
Health Organisation, 1989. ISBN $94-$ Health Or.

Sexuality and Fertility: Christian Ethical Perspectives. Ed C Sethurajan, N M de $S$ Cameron. (Pp x $+60 ; £ 4.95$ paperback.) Edinburgh: Rutherford, 1989 for the Order of Christian Unity. ISBN 0-946068-364.

\section{Intensive care}

Clinical Problems in Acute Care Medicine. J J Heffernan, R A Witzburg, A S Cohen. (Pp xxvi $+731 ; £ 20.50$ paperCohen. (Pp xxvi $+731 ; £ 20.50$ paper-
back.) Philadelphia: Saunders, 1989. back.) Philadelphia: Saunders, 1989.
Distributed by Harcourt Brace Distributed by Harcourt Brace
Jovanovich. ISBN 0-7216-1155-9.

\section{Medical ethics}

Ethics in Paediatric Nursing. Ed G M Brykczyńska. ( $P p x+157 ; £ 9.95$ paperback.) London: Chapman and Hall 1989. ISBN 0-412-32960-3.

Medicolegal

Heinemann Medical Student Reviews. "Medicine and the Law." P A
Knapman, I E West. Series editor P
Richards. (Pp vi $+193 ; £ 8.95$ paperback.) Oxford: Heinemann, 1989 ISBN 0-433-18740-9.

\section{Microbiology}

Infectious Disease and Therapy. Vol 2. "Nucleic Acid and Monoclonal Antbody Probes: Applications in Diagno tic Microbiology." Ed B Swaminathan, G Prakash. Series editors B E Scully, H C Neu. (Pp xxvii +717; figs; $\$ 180$. New York: Dekker. ISBN 0-8247 8023-X.

\section{Nephrology} tional Correlations. Ed CC Tisher, B M ional Correlations. Ed C C Tisher, B M Brenner. (Pp xxxiv +1598 ; fig \&120 two volume set.) Philadelphia Lippincott, 1989. Distributed by
Gower Medical. ISBN 0-397-50779-8 Neurology

Foundations of Neuropsychology. "Neuropsychological Treatment After Brain Injury." Ed D W Ellis, A-L Christensen. Series editor B Uzzell. (Pp x+420; figs; £77.) Boston: Kluwe Academic, 1989. ISBN 0-7923-0014

Management of Facial, Head and Neck Management of Facial, Head and Nech Pain. B C Cooper, F E Lucente. (Pp xiv + 345; figs; £50.) Philadelphia: Saunders, 1989. Distributed by Harcourt Bra

Movement Disorders: a Comprehensive Survey. W J Weiner, A E Lang. (Pp $\mathrm{xv}+735$; figs and colour plates; $\$ 125$. New York: Futura, 1989. ISBN 087993-328-3.

Pain and Headache. Vol 11. "Neurosurgical Treatment of Persistent Pain: surgical Treatment of Persistent Pain:
Physiological and Pathological Mechanisms of Human Pain." J Mechanisms of Human Pain." J M
Gybels, W H Sweet. Series editor P L £88.20.) Basle: Karger, 1989. Distributed by John Wiley and Sons. ISBN 3-8055-4885-0.

Physiological Principles in Medicine. "Clinical Neurology." C D Marsden, M Hobsley, K B Saunders, J T Fitz simons. (Pp xvi+464; figs; £19.95 paperback.) London: Arnold, 1989 ISBN 0-7131-4432-7.

\section{Neurosurgery} xiil 356; figs; colour plates; £93.) ISBN 0-89838-418-4.

\section{Nursing}

Mobility: Patient Problems and Nursing Care. M Judd. (Pp vii+195; figs; $£ 12.50$ paperback.) Oxford: Heinemann Nursing, 1989. ISBN 0-43300167-4.

\section{Nutrition}

Evaluation of Programmes to Ensure Food Safety: Guiding Principles. World paperback.) Geneva: World Health Organisation, 1989. ISBN 92-4154247-0.

Guidelines for Predicting Dietary Intake FAO/WHO Food Contamination Monitoring Programme in collaboration with the Codex Committee on Pesticide Residues. (Pp 24; Sw frs 8 paperback.) Geneva: World Health Organisation, 1989. ISBN 92-4 154250-0.

Nutritional Influences on Illness: $\begin{array}{ll}\text { "Surgery of the Cranial Base." O Al- } & \text { Diseases in Europe." W P T James. }\end{array}$

Gildenberg. (Pp xvi $+442 ;$ figs; T J Fowler. General editors Series. No 24. "Healthy Nutrition: Mefty. Series editor M Salcman. (Pp
xiii +356; figs; colour plates; £93.) back.) Copenhagen: World Health Health Organisation. (Pp 47; Sw frs 9 of Pesticide Residues. Joint UNEP/ Sourcebook of Clinical Research. M
$\mathrm{R}$ Werbach. (Pp viii $+504 ;$ £30.) ISBN 0-7225-1726-2.

The Reverse Effect: How Vitamins and Minerals Promote Health and CAUSE Disease. W A Heiby. (Pp xviii +1198 figs; $\$ 59.50+\$ 8$ surface mail postage. 1988. Available from Mediscience Publishers, PO Box 256A, Deerfield, llinois 60015, USA. ISBN 0-938869$01-9$. Diseases in Europe." W P T James. Organisation Regional Office for
Europe, 1988. ISBN 92-890-1115-7.

\section{Obstetrics and gynaecology}

Prenatal Diagnosis in Obstetric Practice. Ed M J Whittle, J M Connor. (Pp xv+ 274; figs; £29.50.) Oxford: Blackwell Scientific, 1989. ISBN 0-632-01945 $\mathrm{X}$.

Protocols for Gynecologic and Obstetric Health Care. M K Barger, J T Fullerton, V R Lops, M A Rhode. (Pp xii 219; £17 paperback.) Orlando: Grun and Stratton, 1989. Distributed by Harcourt Brace Jovanovich. ISBN 0-8089-1897-4.

Study Guide for Obstetrics: Normal and Problem Pregnancies. S G Gabbe, J R Niebyl, J L Simpson. (Pp viii +139 figs; $£ 16.50$ paperback.) New York: Churchill Livingstone, 1989. ISBN 0443-08529-3.

\section{Oncology}

Cancer Growth and Progression. Vol 7. "Local Invasion and Spread of Cancer." Ed K W Brunson. Series

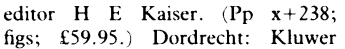
Wellingborough: Thorsons, 1989.

Academic, 1989. ISBN 0-89838-996Clinical Practice in Urology. "Combination Therapy in Urological Malignancy." Ed P H Smith. Series editor $\mathrm{G}$ D Chisholm. (Pp xiii +278; figs; £63.) London: Springer, 1989. ISBN 3-54019528-9.

Psychological Therapy for Patients with Cancer: a New Approach. S Moorey, S Greer. (Pp xiii +233; figs; $£ 14.95$ paperback.) Oxford: Heinemann Medical, 1989. ISBN 0-433-00272-7.

\section{Oral medicine}

An Atlas of Stomatology: Oral Diseases and Manifestations of Systemic Diseases. C Scully, S Flint. (Pp xii +268 ; colour plates; f75. London: Dunitz, 1989. ISBN 0-948269-52-9.

\section{Orthopaedics}

Current Problems in Orthopaedics. "Osteoarthritis in the Young Adult Hip: Options for Surgical Management." D Reynolds, M Freeman. (Pp xii +290 ; figs; £60.) Edinburgh: 